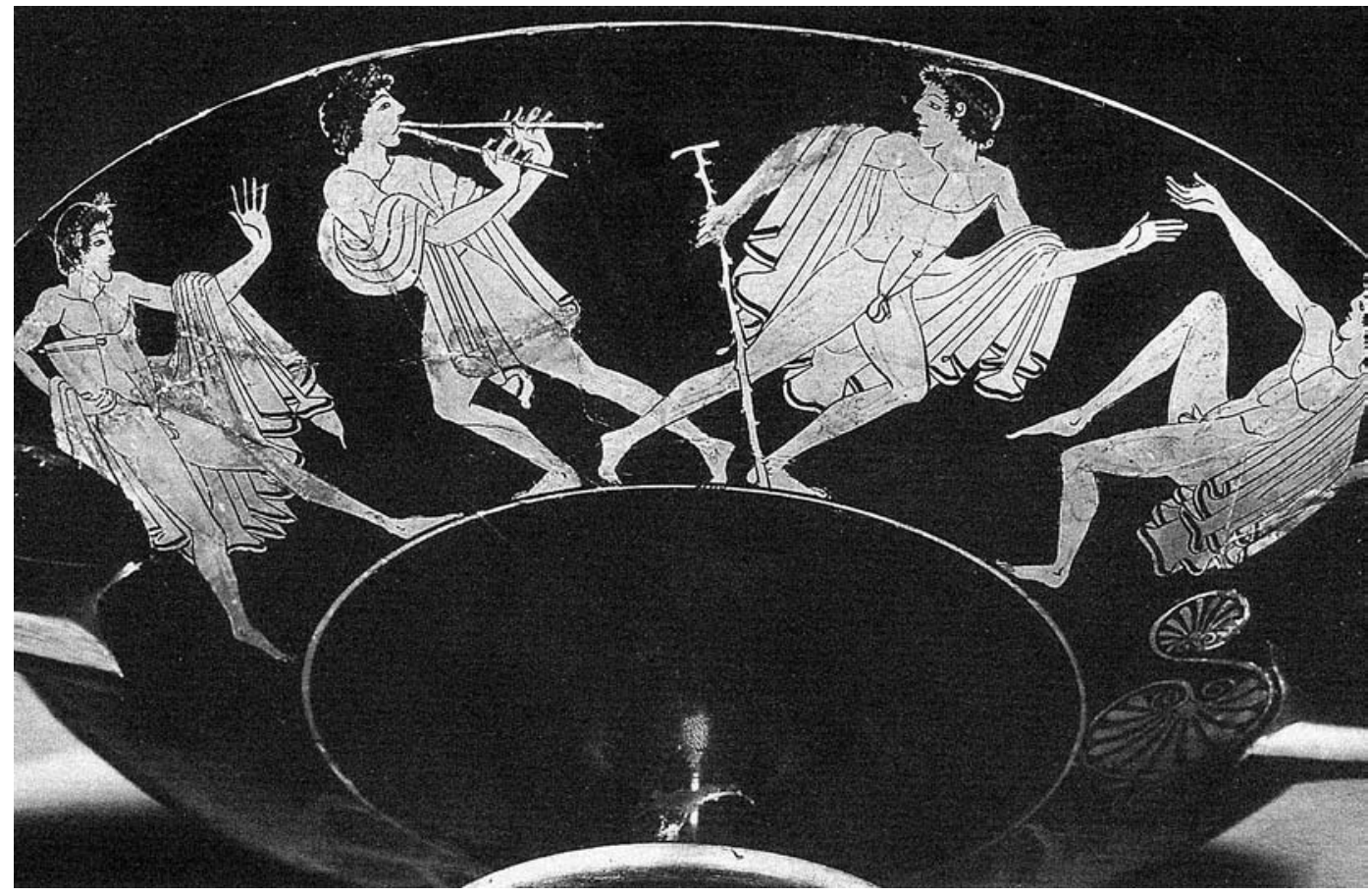

\title{
Vinho e teatro na Grécia antiga*
}

\section{Donato Loscalzo}

0 teatro, como forma literária, nasceu em Atenas no século VI a.C. e a seguir esmoreceu gradualmente, ressurgindo em Roma no século II a.C., em contextos e configurações muito diferentes. Como um rio do Carso, seguiu ao longo dos séculos um percurso irregular, desaparecendo e reemergindo em lugares e tempos diversos. Alguns séculos depois, ressurge na Inglaterra do século XVI, afirmandose depois no resto da Europa até se tornar uma forma adquirida e consolidada na tradição burguesa, principalmente nos séculos XIX e XX.

Este movimento oscilatório deve-se antes de mais à fortuna e ao êxito que o teatro teve ao longo dos tempos junto do público, mas em parte também às resistências que encontrou nas classes elevadas, bem como na oposição de vários intelectuais que fundamentavam com frequência as suas críticas em razões éticas e religiosas. Basta pensar na polémica contra os espectáculos, por parte dos autores cristãos, que Tertuliano encabeçou.

Quando nasceu, na Atenas do século VI a.C., pelo menos nas suas formas embrionárias, foi um momento de festa em honra do deus Dioniso. Era um momento central da Dionísia Urbana, a festa dionisiaca por excelência, que visava exaltar também a grandeza política e económica da cidade. Gradualmente, porém, o teatro perdeu a sua centralidade na vida cultural, mantendo-se contudo como ponto privilegiado de observação dos hábitos e da vida do seu tempo. Em Roma o teatro era uma das formas dos ludos, dos jogos que inicialmente se organizavam para celebrar defuntos nobres ou de excepção, e teve dignidade inferior, e por certo menos público, se os compararmos a outras formas de divertimento como as corridas com carros, os espectáculos com gladiadores, ou as venationes.
No que diz respeito ao mundo grego antigo, os espectáculos teatrais eram frequentados por um público em festa: participante, embora por vezes distraído; critico, embora sempre alegre. Os espectadores tinham a noção de participar num evento festivo e barulhento em homenagem ao deus do tumulto e da embriaguez. Ou seja, tratava-se para eles de um evento religioso, um tributo ao deus Dioniso, mas sempre na base do prazer. Por este motivo, ou seja, por estar ligado ao ritual sagrado das cerimónias comemorativas, deve ser considerado como uma experiência religiosa.

Um público festivo e barulhento é inimaginável para nós hoje, que assistimos aos espectáculos em sala escurecida, enquanto os actores se movimentam num espaço que sobressai pelas luzes. Os seus sons e as suas vozes são recebidos no silêncio de uma sala, um silêncio quase sagrado, interrompido apenas por breves ataques de tosse. Para os antigos, pelo contrário, actores e espectadores dividiam a mesma intensidade de luz, que era a do sol, viviam, portanto, uma dimensão partilhada, e o actor não dispunha de projectores que acompanhassem os seus movimentos ou enfatizassem as suas deixas. Tudo estava determinado pela potência da sua voz, bem como pela expressão do seu movimento.

No mundo moderno o teatro perdeu a sua valência religiosa de tributo aos deuses, aos heróis ou aos homens ilustres, e desvinculou-se da ocasião ritual da festa para se tornar uma forma de divertimento cultural. Mas, paradoxalmente, deste modo adquiriu solenidade, tornandose um espectáculo sério, uma ritualidade com algo de sagrado, já não religioso. Por isso o público que anima as salas hoje em dia é um público correcto, bem vestido, na 
sua maioria silencioso.

Para nós, hoje, ainda não são totalmente claras as razões pelas quais em Atenas o teatro foi um aspecto do ritual em honra de Dioniso. Este deus aparecia aos olhos dos gregos como um deus anómalo, fundamentalmente por ser um deus que morre e renasce, porque tem em si os genes da mortalidade herdados da sua mãe mortal, Semele. As premissas da divindade, pelo contrário, vêmIhe do pai, o deus supremo, Zeus. É anómalo também no panteão aristocrático dos deuses dos Olimpos, porque tem as características populares das divindades dos campos e une em si todos os opostos: é macho e fêmea, é jovem e velho, deus da vida e da exuberância vital, mas também da morte. Se o teatro era um tributo religioso a este deus peculiar, não resulta claro, por outro lado, por que este deus, em todas as representações, aparecia muito raramente e com vestes nem sempre simpáticas (basta pensar nas Rãs de Aristófanes). As razões atribuidas têm-se revelado fascinantes e dignas de interesse, mas a verdade é que o problema permanece em aberto.

Falta ainda referir um dado: no teatro os espectadores antes e durante as representações, bebiam vinho. Isto explica também a sua exuberância e a sua intemperança durante os espectáculos. Existe um testemunho antigo que pode contribuir para iluminar alguns aspectos da presença e da participação do público no teatro, um argumento na verdade pouco estudado e sobre o qual se sabe muito pouco ainda hoje. Filócoro, um historiador do século IV-III a. C., descreve a tradição antiga de comer e beber vinho antes e durante as representações. Segundo o seu testemunho, o público ia ao teatro com a cabeça engrinaldada e depois de ter almoçado e bebido. Enquanto durava o concurso de teatro, servia-se vinho aos espectadores juntamente com petiscos, principalmente bolos. Descreve também que aos coreutas era servido vinho quer quando entravam, quer quando,

FGrHist 328 F $171 . \quad$ acabada a representação, saiam de cena (Pickard-Cambridge 1996: 374).

0 teatro era, portanto, um lugar em que se assistia a

2 Segundo Ateneu (14,

$642 \mathrm{e})$, que relata 0

testemunho de Pânfilo,

estes petiscos seriam

conhecidos como

epaikleia (ou seja serviço extra) por Apione (FGrHist

616 F 32)

${ }^{3}$ Dioniso está presente

no simpósio, ritual

colectivo, sob a forma do vinho que é partilhado

misturado. Por isso fo

introduzida também a

música e o erotismo, mas

sempre sob a forma de possessão ritual (Dupont espectáculos, mas os espectadores usavam grinaldas de flores e bebiam vinho, exactamente como acontecia durante os simpósios. 0 simpósio era uma prática maioritariamente aristocrática, difundida na Grécia arcaica e clássica. Depois de se comer a refeição em familia, recebiam-se visitas ou ia-se a casa de alguém para uma "segunda refeição", de vinho e petiscos, tendo estes por objectivo prolongar o esta a prática do simpósio, muito semelhante aos nossos encontros após o jantar, ocasião de troca de ideias e de conversação sobre os assuntos mais variados, principalmente políticos, de actualidade, de desporto, mas também filosóficos. 0 simpósio não era especializado em nenhum destes assuntos, porque a conversação se animava de maneiras diferentes, de acordo com os participantes e a urgência dos temas a discutir. Tratava-se de uma reunião de homens organizada por alguém que se preocupava em oferecer vinho e outras formas de divertimento aos hóspedes desejo do vinho e abrandar o processo de embriaguez. Era participantes, ou seja aos simposiastas. Estavam, de facto, previstos espectáculos musicais, danças e jogos. No centro triunfava a cratera, o grande jarro onde se misturava vinho e água para os simposiastas que bebiam sempre com medida e contenção. Os participantes, entusiasmados pelo vinho, mas nunca completamente embriagados, discutiam política, entoavam cantos antigos e novos, passavam o tempo desfrutando do prazer e da alegria.

Muitos autores de teatro, principalmente de comédia, referem como se organizavam os simpósios. Aléxis na Policlea (Kassel/Austin: 190) fala em tragemata, úteis para fazer passar o tempo e para não deixar inactivos os maxilares $^{2}$. Efipo no Cidone (Ibidem: 13) refere os petiscos que acompanhavam o vinho e que, segundo Filócoro, circulavam entre o público também no teatro: romã, grão, favas, farinhada, queijo, mel, bolinhos de sésamo, rãs, ovos, sicómoros, bolinhos de trigo torrado, maçãs, nozes, leite, sementes de cânhamo, moluscos, creme de cevada, e uma sobremesa chamada "cérebro de Zeus". Aristófanes n' Os Acarnenses (vv. 1085-1094) faz a lista de tudo o que é necessário para os organizadores do banquete que, juntamente com o sacerdote de Dioniso, preparavam: sofás, mesas, almofadas, carpetes, coroas, perfumes, tragemata, prostitutas, tartes de sésamo, itria (bolinhos de sésamo e mel) (cf. Ateneu, 14, 646d), bailarinas e belas jovens. 0 consumo de bebidas era de noite e os participantes traziam na cabeça coroas de flores: em As mulheres no parlamento, de Aristófanes (vv. 689-92), a personagem que imagina uma sociedade "comunista", Prassagora, propõe fornecer tudo a todos, sem poupar e, em especial, fazer regressar todos às suas casas embriagados, com a coroa na cabeça e a tocha na mão.

Durante o simpósio decorriam cantos e danças festivas à volta de um altar engrinaldado de flores, segundo o testemunho de Xenófanes de Cólofon. Ateneu (11, 463c) fala de conversações sagradas com Dioniso e $(11,464$ e ss.) refere que os atenienses bebericavam vinho e ouviam bobos, mimos e outros artistas ${ }^{3}$. Segundo o testemunho de Teofrasto (11.7), contratavam-se as tocadoras de flautas que faziam parte da animação do banquete. Segundo Xenofonte (Simpósio, 9. 7.), os banquetes terminavam com espectáculos baseados em temas eróticos ou com uma orgia (Álcifron 4. 13).

$\mathrm{Na}$ antiguidade o simpósio era uma prática privada, decididamente aristocrática, organizada pelos abastados que abriam as salas das suas casas a amigos e conhecidos convidando-os para conversarem e para se divertirem. As pessoas comuns, pelo contrário, dedicavam-se a conversas agradáveis apenas por ocasião das festas religiosas que, mesmo assim, eram bastante numerosas ao longo do ano. Muitas fontes concordam em definir a festa religiosa como um momento para beber vinho. Em Atenas uma festa em honra de Dioniso, as Antestérias, assinalava o começo do consumo do vinho novo, em nome do deus. A partir deste momento, em várias ocasiões durante o ano, festejavamse os deuses e os heróis oferecendo vinho aos participantes, 


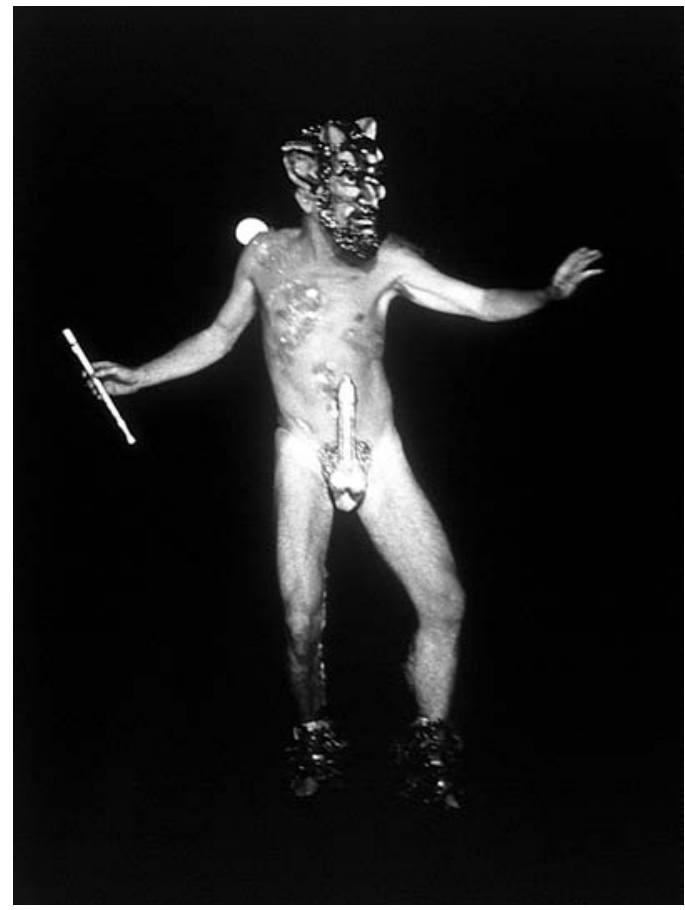

mas só depois de o deus da vinificação ter sido satisfeito. De facto, era necessário primeiro lembrar os deuses para Ihes oferecer o que lhes era devido, e só depois se procedia à festa. Platão (Leggi $6,775 b$-c) afirma que se pode beber até à embriaguez apenas durante as festas de Dioniso, mesmo que isto não seja isento de risco, mas seria desaconselhado embriagar-se durante os banquetes nupciais, onde se pedia sobriedade aos esposos que enfrentavam uma nova vida e iam ter filhos.

0 nexo simpósio-Dioniso é evidente, sendo o vinho o elemento basilar desta forma de divertimento. A fonte de Filócoro é útil para explicar porque em Atenas o teatro foi originariamente um momento do culto em honra do deus Dioniso, dadas as analogias com o simpósio. 0 nexo vinhoteatro torna então compreensivel o nexo Dioniso-teatro. Até hoje nunca foi dado realce ao testemunho de Filócoro, segundo o qual os participantes dos espectáculos de teatro bebiam vinho e usavam coroas de flores. Isto é, o público no teatro portava-se como se portavam os participantes de um simpósio. Também no teatro se bebia vinho e se comiam bom petiscos para acompanhar as bebidas.

Aristoteles (Ética a Nicómaco 10, 1175b 12) regista que se comiam tragemata principalmente quando os actores eram mediocres, compensando o escasso prazer que vinha da cena com o que podia vir dos bolinhos.

0 público no teatro bebia vinho e comia petiscos enquanto assistia a espectáculos tal como acontecia nas casas privadas. 0 deus do vinho protegia ambas as ocasiões festivas e cedo se tornou a figura tutelar e o destinatário do teatro. Pode colocar-se a hipótese de que o teatro não passasse de um simpósio organizado pela cidade democrática para os seus cidadãos. A democracia na Atenas clássica configurou-se como uma extensão das liberdades e dos privilégios aristocráticos a uma massa mais numerosa de individuos e, neste contexto, o teatro tornou-se um simpósio para muitos. A cidade encarregava-se da sua organização, como o magnata aristocrático se preocupava em organizar simpósios para o círculo fechado dos seus amigos.

\section{As bacantes, \\ de Euripides, \\ enc. Fernanda Lapa, \\ Escola de Mulheres, 1995 (João Grosso), \\ fot. C. Fabião.}

Para além disso, o teatro foi associado ao deus do vinho, porque a cidade achou este momento essencial para a formação de uma mentalidade política dos seus cidadãos. A experiência teatral, de facto, cimentava a consciência de pertencer a um contexto, assim como durante séculos o simpósio teve a função de cimentar o sentido de pertença a um grupo desses notáveis que se reuniam nas salas destinadas ao consumo colectivo de bebidas.

Se o teatro é divertimento organizado pela cidade, justifica-se o consumo do vinho, em quantidade limitada, obviamente, mas como ingrediente de base. Desde sempre as várias formas de divertimento foram marcadas pelo consumo de bebidas. Beber com os outros significa tornar mais confortável, aberta e livre a conversação. Entreterse, encontrar-se, conversar são actos que fazemos acompanhando-os com alguma bebida. Hoje esta prática é acompanhada por uma ampla série de bebidas, vinho, licores, café, chá, chocolate entre outras coisas. Na sociedade grega esta função cabia principalmente ao vinho, porque eram desconhecidas quase todas as bebidas que temos hoje ao nosso dispor.

Resta-nos perceber quem oferecia vinho e petiscos aos espectadores. Muito provavelmente era o corego, quem estava encarregado das despesas de montagem do espectáculo, muitas vezes para tentar obter o favor do público e do júri que, nos concursos teatrais em honra do deus, deviam atribuir a vitória a um dos dramaturgos a concurso. Os juizes, de resto, deviam ser condicionados no seu juizo também pela aceitação do público. 0 que nos diz Aristófanes a este respeito é inequívoco: $n^{\prime}$ As vespas (vv. 58-59), ele gaba-se de apostar na qualidade da sua arte para atrair a atenção e a aceitação do público e de não recorrer a servos que atiravam nozes aos espectadores para ter o seu favor. Do mesmo modo em Pluto (vv. 797799) sentencia que não é desejável que um poeta cómico atire ao público, para o forçar a rir, figos secos e trogalia, ou seja tragemata, petiscos que acompanhavam o consumo do vinho. Lembra, a seguir, o hábito de um certo Dessinico de se pôr de pé para agarrar mais figos (v. 800 s.). Eram, 
provavelmente, distribuições simbólicas, limitadas às primeiras filas, porque só dois escravos não podiam percorrer todos os degraus.

0 teatro foi, afinal, fundamentalmente um "simpósio alargado", um simpósio democrático. Aristófanes no final de As mulheres no parlamento (vv. 136-1143), representa uma Serva que convida Blepiro para almoçar, aproveitando que tinha sobrado vinho de Quios e outras coisas boas. Mas o convite é alargado também ao público: "se houver alguém entre os espectadores que nos aprecia, se houver algum juiz que não defenda outros, também serão hóspedes bem-vindos, que poderão dispor de tudo o que há". 0 teatro estava, pois, ligado à vida da democracia, era um momento de encontro e discussão de problemas que diziam respeito à vida do homem na família (a tragédia) e do indivíduo na comunidade (a comédia). No caso da tragédia, são as conversações entre os indivíduos e o diálogo que animam a história, aprofundando problemáticas existenciais; no caso da comédia, pelo contrário, a assembleia está no centro de muitas representações, por ser a instituição política destinada à troca de opiniões. Muitas comédias antigas centravamse na representação de momentos das assembleias. Filosofia e política, ética individual e conduta comunitária são as duas almas do teatro antigo. Os mesmos factores cabiam no simpósio aristocrático, que era privado, enquanto que no teatro podia entrar toda a gente.

A polis democrática ateniense alargou esta prática que tinha em Dioniso o seu referente cultural e religioso e transformou-a numa instituição comum, para todos os cidadãos. 0 teatro foi, num certo sentido, o simpósio colectivo e dele herdou, como vimos, muitos traços. Em primeiro lugar, o deus do simpósio é também o deus do teatro, e o vinho é o instrumento através do qual ele chega aos homens. Em segundo lugar, estas reuniões ocorriam sob o signo do canto e da dança. Em terceiro lugar, o simpósio é lugar de discussão política, como se viu, e assim será também o teatro que, através das suas duas almas (a trágica e a cómica), irá reproduzir em cena os dois momentos da poesia: a da laude elegíaca, e a da reprovação e invectiva jâmbica. Não é por acaso que os estudiosos modernos reconduziram a comédia ao jambo $\mathrm{e}_{1}$ acrescentariamos, também a tragédia poderia reconduzir-se à elegia. Os dois géneros previam o acompanhamento do aulós (flauta), o mesmo que acompanhava o canto do coro no teatro.

Existe uma voz digna de confiança a esse respeito, que documenta o fundamento desta tese: Sócrates, segundo o testemunho de Plutarco em A educação das crianças (10c), definira o teatro como um grande simpósio. Fortes são, de resto, as analogias entre o simpósio e a assembleia pelas coincidências culturais: desde o tempo arcaico o simpósio era sede das deliberações dos grupos aristocráticos, assim como a assembleia o era das cidades (Vetta 1994: 156).

Exactamente pelo facto de o teatro ser o elemento catalizador da vida cultural e política ateniense, muitos intelectuais olharam com espírito crítico para este género literário. 0 estadista Cleón acusava os seus concidadãos de serem "espectadores de palavras" (Tucídides 3. 38. 4) e são bem conhecidas as polémicas ligadas à função corruptora da tragédia no livro X da República de Platão. A sensação era a de participar numa assembleia, a de assistir a uma discussão que se tornava espectáculo. Obviamente não era só esta a razão pela qual se ia ao teatro, mas devia constituir um elemento importante. Também antes da Assembleia se bebia vinho segundo Aristófanes em As mulheres no parlamento, 128 ss.) e quem tinha intenção de falar usava a coroa. A cerimónia de abertura de uma assembleia é descrita pelo orador Ésquines (1. 23) que lembra ter dado uma volta ao recinto com um porquinho, enquanto 0 arauto recitava preces, e depois punha-se a votos a ordem do dia. A seguir o arauto dava a possibilidade a cada um de usar da palavra. Em As mulheres no parlamento (v. 305 ss.), Aristófanes lembra o hábito dos tempos anteriores, quando cada um ia para a assembleia levando um odre para beber, pão, duas cebolas e três azeitonas.

\section{Referências bibliográficas}

ARISTÓFANES (1907), Comoediae, ed. Frederick William Hall / William Martin Geldart, Oxonii e Typographeo Clarendoniano.

ARISTÓTELES (1996), Etica nicomachea, ed. Claudio Mazzarelli, Milano, Rusconi.

ATENEU (2001), Deipnosofisti: i dotti a banchetto, trad. Luciano Canfora; introd. Christian JACOB, Roma, Salerno.

FGrHist: Die Fragmente der griechischen Historiker, von Felix JACOBY, Leiden, E. J. Brill, 1923 ss.

HENDERSON, Jeffrey (1991), The Maculate Muse: Obscene Language in Attic Comedy, New York / Oxford, Oxford University Press.

KASSEL, Rudolf / AUSTIN Colin (1983-2001), Poetae comici graeci, Berolini, Novi Eboraci.

PICKARD-CAMBRIDGE, Arthur (1996), Le feste drammatiche di Atene, trad. it. (Oxford 1988), Firenze, La Nuova Italia.

PLATÃO, (2005), Leggi, ed. Franco Ferrari / Silvia Poli Milano, Biblioteca Universale Rizzoli.

PLUTARCO (1987), De l'éducation des enfants, in Plutarque, Oeuvres morales, I, ed. Jean Sirinelli, Paris, Les belles Lettres.

TEOFRASTO (2004), Characters, ed. James Diggle, Cambridge, Cambridge University Press.

TUCIDIDES (1960), Historiae, ed. Otto Luschnat, Leipzig, Bibliotheca scriptorum Graecorum et RomanorumTeubneriana.

VETTA, Massimo (1994), Aristofane: Le donne all'assemblea, a cura di Massimo Vetta, trad. Dario Del Corno, Milano, Mondadori, Fondazione Lorenzo Valla.

XENOFONTE (2003), Simposio, ed. Anna Giovannelli, Milano, La vita felice.

* Todas as traduções do grego clássico são de autoria de Donato Loscalzo.

Tradução de Sebastiana Fadda 